\title{
Mimaride Geçicilik Kavramının Sergileme Yapıları Üzerinden Değerlendirilmesi
}

\author{
Betül GÖK ${ }^{1 *}$, Onur ERMAN²
}

Öz

Bu çalışma, kamusal alanda örnekleri sıklıkla görülmeye başlanan geçici yapıları odağına almaktadır. Yaşamının belli bir süre devam edip sonlanacağını bilen insanoğlu zamana karşı koyma gayreti içerisinde, varlığını temsil edecek kalıcı bir eser bırakma mücadelesindedir. Kalıcılığı ifade etmede mimari daima bir araç olmuştur. Zamanın ilerleyişi ile toplumlarının tüketim odaklı olması, teknolojik gelişmeler, intiyaçların farklılaşması, yaşam biçiminin değişmesi gibi sebepler insanoğlunu yaşantıda geçici unsurlara doğru yöneltmiştir. Bu değişimin bir yansımasının yaşantının yansıması olan mimaride görülmemesi mümkün değildir. Hızlı yaşam biçimi, yaşantının çeşitlenmesi, değişimin artmasına böylelikle stabil olanın yerine hareketli ve değişebilen mekânların ortaya çıkmasına sebep olmuştur. Bu durumun en iyi gözlenebildiği örnekler genellikle kamusal alanlarda kısa süreli kullanımlar için tasarlanan geçici yapı türleridir. Çalışmada geçici yapılar pavilyon örnekleriyle değerlendirmeye alınarak, bu yapıların gelişimi ve değişimi tespit edilerek, mimari özellikleri belirlenmeye çalışılmıştır. 1900-2020 yılları arasında inşa edilmiş pavilyon örnekleri periyodlara ayrılarak, biçimsel, işlevsel, strüktürel, bağlam ve malzeme özellikleri bakımından değerlendirilmiş ve sonuçlara ulaşıımıştır. Ulaşılan sonuçlar geçici yapıların kullanımının ve bağlamının zaman içinde değiştiğini, yakın dönem örneklerinin çoklu kullanıma sahip olduğunu ve kamusal alanı bağlam edindiğini göstermektedir. Ek olarak biçimsel, strüktürel ve malzeme bakımından ise geçici yapıların dönemin öncü uygulamalarına sahip olduğu görülmüştür. Bu bakımdan geçici yapılar mimarlık pratiğinin laboratuvarı olarak kabul edilebilir.

Anahtar Kelimeler: Zaman, Geçicilik, Geçici Mimarlık, Mimari Mekân, Sergileme Yapıları

\section{Evaluation of Ephemerality Concept in Architecture Through Pavilions}

\begin{abstract}
This study focuses on examples of the temporary structures that have been frequently seen in the public space recently. Human beings, who know that their life will continue and end for a certain period of time, is in the struggle for existence against nature and other living things in an effort to resist time. All these efforts are the reason of the desire of the human beings to leave a permanent object that will represent their existence. Architecture has always been a tool to express the desire of the human being to be permanent. The advancement of time, technological developments, the differentiation of needs and the change in lifestyle created the consumption-oriented societies that have led human beings to temporary elements in life. It is not possible that a reflection of this
\end{abstract}

\footnotetext{
1 İstanbul Gelişim Üniversitesi, Mühendislik ve Mimarlık Fakültesi, Mimarlık Bölümü, İstanbul, Türkiye

2 Çukurova Üniversitesi, Mimarlık Fakültesi, Mimarlık Bölümü, Adana, Türkiye

Bu çalışma, Çukurova Üniversitesi, Fen Bilimleri Enstitüsü, Mimarlık Anabilim Dalı, Yüksek Lisans Programında tamamlanan "Mimaride Geçicilik Kavramının

Sergileme Yapıları Üzerinden Değerlendirilmesi" başılılı yüksek lisans tezinden üretilmiştir.

* İlgili yazar/Corresponding Author: begok@gelisim.edu.tr, betullgok17@gmail.com
}

Gönderim Tarihi / Received Date: 30.05.2021

Kabul Tarihi / Accepted Date: 22.11.2021 
change is unavailable in architecture, which is a reflection of life. The fast-moving way of life, the diversification of lifestyle, the increase in change, cause the emergence of active and rapidly changed spaces instead of stable and fixed ones. The best example of this statement is temporary structures which were designed for short-term use in public spaces. In this context, temporary structures were evaluated by means of pavilion samples in the study. The development and variation of these structures were defined and their architectural features were determined. Pavilion samples built between the years of 1900 and 2020 were divided into periods and evaluated in terms of formal, functional, structural, contextual and material properties and the results were obtained. The results show that the use and context of temporary structures has changed over time, that recent examples have multiple uses and take the public space into context. In addition to these, it has been observed that the temporary buildings had pioneering practices in terms of form, structure and material of the period they were built. In this respect, temporary structures can be regarded as the laboratory of architectural practice.

Keywords: Time, Ephemerality, Ephemeral Architecture, Architectural Design, Pavilion

\section{Giriş}

Geçmişten günümüze ulaşmış en fantastik düşüncenin, insanın zamana karşı verdiği savaşı kazanarak ebediyen var olma fikri olduğu söylenebilir. Zaman var olmanın anahtarı, bir bakıma ortamı olurken aynı zamanda yaşam için bir kısıt ve kontrol aracıdır. İnsanoğlu tüm yaşantısını, görev ve sorumluluklarını, iş planını zamana bağımlı kararlar çerçevesinde düzenler ve gerçekleştirir. Zaman, kaçınılmaz biçimde hayatı yönlendiren ve biçimlendiren bir olgudur. Günümüzün hızlı yaşam temposu, zamanın geçiciliğini daha da güçlendirerek, onu en verimli şekilde kullanma düşüncesini ortaya çıkarmıştır (Aksakal, 2011, s. 112). Bu durum özellikle hem kalıcı olmanın değerini yükseltmiş hem de kalıcı olan her şeyi daha ilgi çekici hale getirmiştir. Zamana karşı koyma ve yaşlanmama isteğine yanıt veren gençleştirici kremlere, kalıcı makyaj gibi koruyucu uygulamalara olan ilginin yanında daha uzun süre kullanımı mümkün her türlü ürünün bu bakımdan cazibesi olduğu ifade edilebilir. Yiyeceklerin daha uzun süre tazeliğini koruyacağını iddia eden buzdolapları, daha uzun süre dayanıklı olabileceği düşünülen teknolojik ürünlerin tümünün, zamanın geçiciliğine ve insanın ölümlülüğüne karşı tepki olarak yorumlanabilir (Cebriloğlu, 2016, s. 375). Özellikle fiziksel zamanda geri dönememe, zamanın biteviye ilerleyişinin insanların kalıcı olma isteğini pekiştirdiği düşünülmektedir. Böylece kalıcı olmak, geçici olmaya göre daha önemli ve kıymetli hale gelmektedir. İnsanoğlu, geçici, ölümlü bir varlık olduğunun farkındadır ve buna karşıık olarak dünyada bir iz bırakma çabası içerisindedir. Ölümlüğünün bilincinde olan insan, kalıcı olmaya daha çok değer vererek hayatında, varlığının her evresinde kalıcılığı aramaktadır. Bir bakıma üretilen yardımıyla zamanı durdurma isteği olarak yorumlanabilecek bu gayret, kimi zaman sanatta kimi zaman da bilimde ortaya çıkmaktadır. Munch'ın 22 Ocak 1892 tarihli günlüğünde yer alan notları şöyledir; "ìki arkadaşımla yol boyunca yürüyordum - güneş battı - bir melankoli hissettim - aniden gökyüzü kanlı bir kırmızıya döndü. Durdum, korkuluklara yaslandım, ölümden yoruldum - mavi-siyah fiyortun ve şehrin üzerinde alevli gökyüzü kan ve kılıç gibi asılıyken arkadaşlarım devam etti - orada kaygıyla titreyerek durdum - ve sonsuz bir çığlık hissettim doğanın içinden." (URL-1). Munch'un hislerine neden olan ve bir lahza sonra kaybolabilecek bir görüntü sanat eserinde sonsuzlaşırken, eserin aktardığı duygu ile o ana ait her şey kalıcı hale gelmiştir (Şekil 1). 


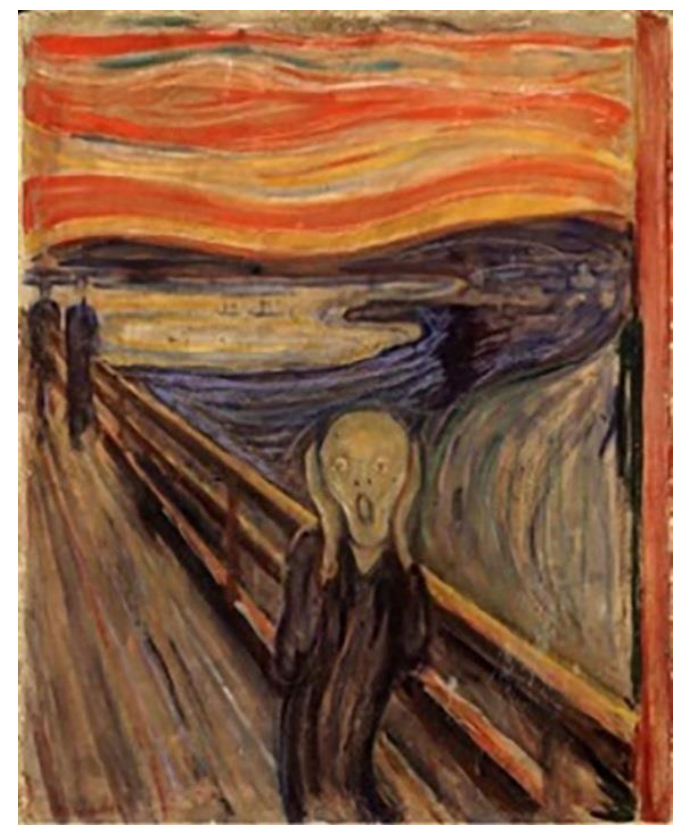

Şekil 1. The Scream (Çı̆̆lık), E. Munch, 1895. (URL-1).

İnsanlar çağlar boyunca zamanın akışını ve gelip geçici oluşunu derinlemesine sorgulamıştır. Zamanın mutlak olmadığını kanıtlayan Albert Einstein (1879-1955), uzamsal ve zamansal değerlerin gözlemcinin o an bulunduğu yere göre değişiklik gösterdiğini söylemektedir. Bu açıdan zaman kavramının sürekli bir değişim içinde gelip geçici bir hal olduğu açıktır. Alvin Toffler (1974) geçiciliği, zaman kavramını belirleyen değerlerden biri olarak tanımlar. Bu tanım; zamanın geçiciliğini zamanla ilişkili olan ve zamanla birlikte var olan nesnelere yansıtır. Fiziksel zamanın doğrusal ilerleyişi ve zamanda geriye dönememe hali, nesnenin kaybının kalıcı, durumunun ise geçici olmasına neden olur. Örneğin cam bir bardak kırılana kadar kalıcıdır. Bardak kırıldığında ise zamana göre durumu geçici ve bunun aksine kırık olma durumu ise artık kalıcı hale gelmiştir.

Her ne kadar insanoğlu kalıcı olmayı arzulasa ve bu yönde arayışları olsa da içinde yaşanılan çağın koşulları geçiciliği hayatın bir parçası haline getirmiştir. Bu paralellikte, zamanın yaşantı ve toplum üzerindeki etkileri, zaman içinde görülen değişimler insanın nesnelerle olan ilişkilerini de etkilemektedir. Örneğin teknolojinin sağladığı kolaylıklarla daha hızı hale gelen yaşantıda nesnelerle kurduğumuz ilişkinin süresi de kısalmaktadır. Bu süre kimi durumda bir işi daha yapmak için nesnenin kullanım süresi, kimi durumda da nesnenin kullanım ömrü olarak değerlendirilebilir. Teknolojinin beraberinde gelen hız, bir yandan tüketim kültürünün artmasına ve yaşantıda hızın ivme kazanmasına, geçici kullanımların dolayısıyla geçici nesnelerin çoğalmasına sebep olmuştur. Özellikle modern yaşantıda nesnenin varlığı da hızla tanımlanmıştır. Tek seferlik plastik kaplar, kâğıt peçeteler, mendiller, havlular ve şişelerin tümü çabucak kullanılacak ve atılacaktır. Hazır tüketilen yiyeceklerin kapları ancak yemek yendiği süre içinde geçerliliğini koruyabilecektir. Bu açıdan nesnelerle kurulan ilişkinin süresinin de yaşam hızıyla doğrudan ilişkili olduğu söylenebilir. Öte yandan hız ve geçicilik, nesnelerin kullanımında duyguları etkilemekte, nesnelere karşı takınılan tavırlar, temel değer yargılarındaki değişimi yansıtmaktadır. Uygun şartlarda kullanıldığında kıymetli birer nesne olarak belki nesilden nesle aktarılabilecek yemek tabakları, çatalların yerini bir öğünde kullanılıp işi biten ürünler almaktadır. Bu durum nesneleri değersizleştirmekte, kalıcı olmanın önemini azaltmaktadır. "Kullan-at" kültürünün bir sonucu olan bu durumda nesneler ancak kullanıldıkları süre zarfında vardır (Toffler, 1974, s. 52). Dolayısıyla nesnenin varlığı ancak kullanıldığı-işe yaradığı süre ile sınırıdır. 
Dünyanın adeta daha hızlı döndüğü bu günlerde, yaşamın hızının mimarlı̆̆ı etkilememesi mümkün değildir. Mimarlık ve yapı elbette kullan-at nesnesi değildir. Ancak gelişmelerle birlikte, belli dönemlerde kullanılır olmak, işlevini tamamladığında sökülüp toplanmak, kaldırılmak veya yer değiştirmek mimari için olağan hal almış̧ır. Bu açıdan konuyu ele alan çalışmanın amacı mimaride geçicilik kavramını odağına alarak, geçici yapıların karakteristik özelliklerini değerlendirmektir. Bu amaçla mimari bir yapının biçimlenmesini sağlayan beş ana unsur olarak sayılabilecek strüktür, malzeme, biçim, işlev ve bağlam kavramları kullanılarak değerlendirmeler yapılmış, karşılaştırmalarla sonuca ulaşılmaya çalışılmıştır.

\subsection{Doğada geçiciliği anlamaya çalışmak}

Geçiciliği tanımlama çabası, doğada bulunan örneklerle geçiciliğin doğal ve yapılı çevredeki rolünü inceleyerek başlamaktadır. Böylece doğrudan doğal döngüleri anlayıp zaman ve doğa arasındaki bütünleşik ilişkilerle kolayca ilişki kurulabilmektedir (Chappel, 2004, s. 4). Doğadaki tüm canlı varlıklar da birçok nesne gibi aslında geçicidir. Geçicilik olgusu doğanın özünde var olan ve tekrar eden bir durumdur. Tüm canlı varlıkların hayatlarının doğum, yaşam ve ölüm üçgeni içinde döngüsel devam etmesi bu duruma bir örnektir. Döngüyle birlikte beliren durum, yaşanan değişim nedeniyle geçici bir hal alırken, geçiciliğe neden olan değişimin bir olgu olarak sürekliliği olduğu söylenebilir. Bu bakımdan değişim, doğada kalıcı olabilmenin bir yöntemidir. İçgüdüsel olarak kalıcı olmaya çalışan canlılar değişerek doğada varlığını sürdürür.

Biyolojik olarak geçici olmak ise ömür ile ilişkilendirilmektedir. Bu bakımdan mevsim bitkileri veya neredeyse 24 saatlik kısa ömürlü böcekler doğada geçiciliğe birer örnek sunmaktadır. Bazı bitkiler ve çölde bulunan bazı çiçekler, kısa ömürlerinden ve her yıl çiçek açmamalarından dolayı genellikle 'geçici' olarak bilinmektedirler. Bu bitkiler arasında yalnızca ortamda su bulunduğunda çiçek açan Desert Paintbrush sayılabilir (Şekil 2.a). Bitki yağmur yağdığında, birkaç gün veya hafta içinde tüm yaşam döngüsünü tamamlayıp, bir sonraki yağmuru bekleyerek uykuya geri dönmektedir. Doğadaki bu durum tekrarla ve döngülerle gerçekleşen geçiciliğin koşullarla ilişkili oluğunu göstermektedir. Kısa ömürlü bir başka grup olan birçok böcek ise varlıklarının büyük çoğunluğunu, gelişim evrelerinde geçirmektedir. Bazı böceklerin yetişkinlik evresi birkaç gün, saatler veya sadece birkaç dakika sürebilmektedir. Bu türün bir örneği olarak Mayıs sineğine 48 saatten az bir sürede hayatta kalmasından dolayı Latince geçici anlamına gelen "Ephemeroptera" adı verilmiştir (Şekil 2.b). Yaşam süreleri havaya, mevsime veya Ay'ın hareketleri gibi döngüsel olaylara bağlı olan bitkiler, böcekler ve doğal olaylar, içsel olarak doğanın sürekli değişimine ve döngüsüne işaret etmektedir (Chappel, 2004, s.13).

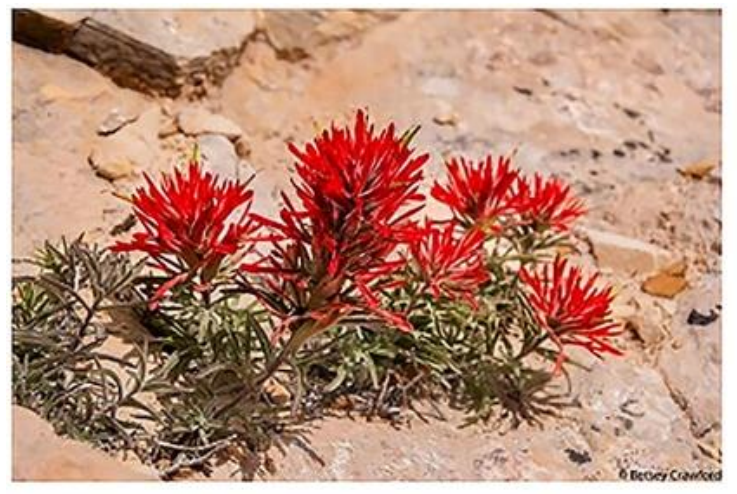

(a)

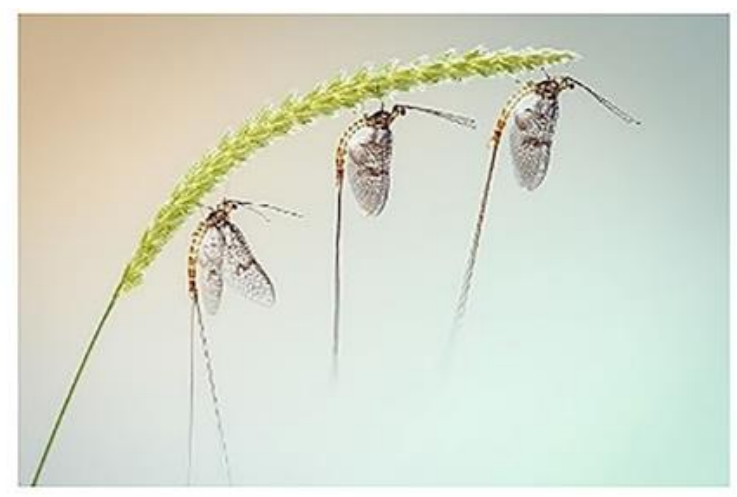

(b)

Şekil 2. Doğadaki Geçici Canlılar a) Desert Paintbrush Bitkisi (URL-2), b) Mayıs Sineği (URL-3). 
Her canlı biyolojik bir varlık olması nedeniyle elbette geçicidir. Ancak canlıları diğerlerine göre daha kalıcı ya da geçici kılan unsur şüphesiz zaman faktörüdür. Çok uzun ömürlü bir canlı için bir yıl çok kısa bir zaman dilimini ifade edebilirken, bir kelebek için bu zaman dilimini deneyimlemek imkânsızdır. Bir fil koşulsuz biçimde bir kelebeğe göre dünyada çok daha uzun süre kalıcıdır. Bu yargı, filin kalıcı olma durumunu kelebeğe göre daha uzun süre koruduğu şeklinde yorumlanabilir. Ancak filin geçiciliğini ortadan kaldırmaz. Böylelikle varlığın geçici oluşunun zaman bakımından göreceli olduğu söylenebilir.

\subsection{Mimaride geçicilik ve kısa tarihçesi}

İnsanoğlu, korunmak ve barınmak amacıyla çeşitli tiplerde geçici yaşama birimlerini meydana getirmiştir. Bu birimler, kimi zaman hayvan kemikleri kimi zaman ağaç gövdeleri gibi doğal, bitkisel malzemeler ve kimi zaman da hayvan derisinden elde edilen barınaklar olmuştur (İzgi, 1999, s. 27). Geçici yerleşimlerde kurgulanan mekânlar için maksimum mobilite, özgürlük ve esneklik kavramları öne çıkmaktadır (Chappel, 2004, s. 3). Ek olarak küçük boyutlu ve basit özellikte olan bu mekânlar, ustalık gerektirmeden, hafif ve kolaylıkla şekil verilebilen malzemelerle, hızlıca kurulabilen yapısal özelliklere sahiptir. Bu bakımdan çadır, basit, tekrar monte edilebilen ve portatif bir özelliğe sahip olmasından dolayı geçici yapı örnekleri arasında sayılabilir. Bu bakımdan tarihsel bağlamda geçici yapılar, kısa süreli kullanılan, yerel malzemeden yapılan, temel intiyaçlara cevap verebilen, bulunduğu coğrafyanın iklimine uygun bir şekilde geçici olarak kullanılan barınaklardır.

Geçtiğimiz yüzyıllarda etkin olan mekân anlayışları sosyal, kültürel ve ekonomik yapılarıyla değişimlere uğramıştır. Değişen toplumsal değerlerle değişen mimari mekân, kavramsal, işlevsel ve estetik olarak yeni boyutlar kazanmıştır. Mekânın değişime uğradığı en kritik an belki de insanoğlunun yerleşik hayata geçtiği dönemdir. Bu değişimin en önemli yansıması biçimde ve malzeme kullanımında görülür. Antik dönemde mekândan bağımsız biçimlenen kütleler, malzemenin olanakları ile inşa edilebilmekteydi. Kalıcı olmak tamamen biçim ve malzeme ilişkisine dayanmaktaydı. Bugün bile hayranlıkla seyredilen Mısır Piramitleri, mekân inşa etmekten çok, adeta insanın dünyada iz bırakma çabasının, kalıcı olma arayışının bir göstergesidir.

Zaman içinde geçici yapılar barınmanın yanında başka amaçlar için de inşa edilmeye başlanmıştır. Özellikle Rönesans ve Barok döneminde yaygın kullanılan geçici yapılar, yas ve taç giyme törenlerinde, evlilik, doğum ve zafer gibi kutlama zamanlarında meydanlarda, sokaklarda inşa edilmiştir. Sembolik görüntüleriyle öne çıkan bu yapılar tören sona erdiğinde, tekrar kullanılmamak üzere sökülmekteydi (Chabrowe, 1974, s. 385-391). Geçici yapılar, erken modern döneme yaklaşıldığında önceki dönemlerde görülen sembolik değerini korumakla birlikte, değişen toplumsal yaşama bağlı olarak çeşitlenen kullanımlarla kendini göstermeye başlamıştır. Bu yapılar ilk olarak 'pavilyon' adı altında, soyluların saray bahçelerinde, peyzaj unsuru olarak bir süs, belirgin bir işlevi olmayan küçük bir mimari yapı türü şeklinde görülmeye başlanmıştır (Robinson, 2014, s. 3) (Şekil 3.a).

Modernizmin temelini atan Endüstri Devrimi ve beraberinde gelen teknoloji, yapı inşa tekniğini değiştirmekle birlikte mimaride mekân ve biçim kavramının da yeniden ele alınmasını sağlamıştır. Modernizmin mimaride yarattığı en önemli farklılık, mekân ve biçim ilişkisinde işlevin etkin bir role bürünmesi olmuştur. Erken modern dönemde sanayinin ve teknolojinin öne çıkması yeni bir kullanım olarak sergileme alanlarını ortaya çıkarmıştır. Kültürel faaliyetler, uluslararası etkinliklerde sıklıkla karşılaşılan bu türün aynı zamanda kendini sergilemesiyle toplumu ve dünyayı, kullanılan malzeme ve yapım yöntemi teknolojilerindeki gelişmelerden haberdar eden bir yapı türüne dönüşmüştür. 
Dönemin ruhu da dikkate alındığında erken Modernizmin geçici yapı türleri fuar ve sergi yapıları olarak dikkat çekmektedir. Örneğin 1889 yılında Fransa'da düzenlenen Dünya Fuarı için geçici olarak inşa edilen Eiffel Kulesi günümüzde dünyanın en çok bilinen yapılarından bir tanesidir (Şekil 3.b). Dünya Fuarı, Fransız İhtilali'nin (1789) 100. yıldönümünü kutlamak amacıyla düzenlenen uluslararası bir fuardır. Fuarın giriş kapısı olarak inşa edilen yapı, her ne kadar inşasından 20 yıl sonra yıkılmak üzere inşa edilmiş olsa da Paris kentine simgesel katkısı, fizik ve meteoroloji bilimleri için sağladığı olanaklar ve radyo sinyallerinin dağııımında oynadığı rol sebebiyle günümüze kadar ayakta durmayı başarmıştır (URL-4). Yapı, geçici amaçla inşa edilmiş olmasına rağmen ironiktir ki imgesel ve işlevsel olarak hedeflenenden çok daha kalıcı olmuştur.

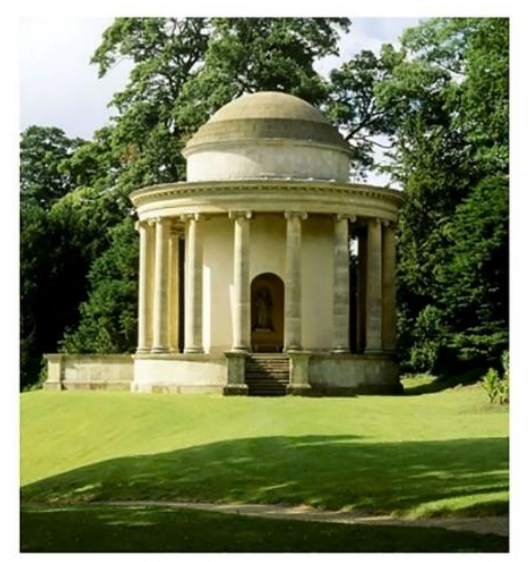

(a)

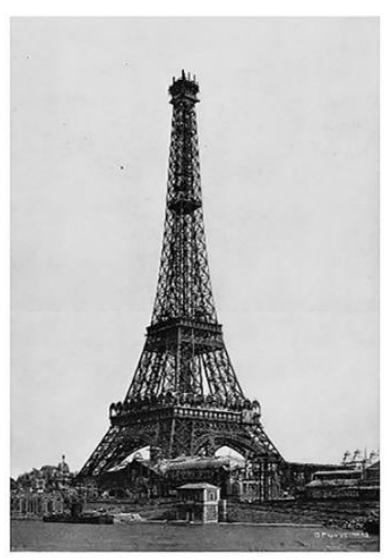

(b)

Şekil 3. a) Temple of Ancient Virtue, W. Kent, 1734, (URL-5); b) Eyfel Kulesi, G. Eiffel, S. Sauvestre, 1886-1889, (URL-4).

\section{Geçici Mimari Yapıların Karakteristik Özelliklerinin Belirlenmesi}

Geçici mimari, belirli bir süre sonra bulunduğu alandan kaldırılarak fiziksel olarak yok olması için tasarlanan geçici karakterdeki yapı grubunu tariflemektedir (Chappel, 2004, s. 23). Mimari bir yapı, yıkılıp yok olması yüzyıllar alsa bile sonuçta yok olacaktır. Ne kadar geçici oldukları ise yapımlarında kullanılan malzemelerden strüktürüne bulundukları yerin bağlamına kadar birçok farklı değişkene bağlı olarak belirlenmektedir (Arun, 2012, s. 29). Ancak geçici mimari, bilinçli bir şekilde yapının fiziksel ömrünün kullanım süreciyle ilişkilendirilerek geçici olması tasarlanan yapılardır.

Ülkeler arasında rekabetin gözlendiği ve ulaşılan teknolojinin sergilendiği EXPO fuarları geçici yapıların tanımlanmasında ve meşrulaşmasında bir dönüm noktası olmuştur. Nitekim Crosby (1968) EXPO'67 Montreal Dünya Fuarı'nın ardından yazdığı kritikte geçici olmak için tasarlanmış pavilyonların kalıcı yapılardan mutlaka farklı olmaları, belirli bir süre kullanılmak bir anlamda harcanmak için inşa edilen bu yapıların hafif, ucuz ve kısa sürede inşa edilebilir olmaları gerektiğini ifade eder. Bu bakımdan geçici mimari özellikleri ve olanakları sayesinde, kalıcı yapıların tasarımında gelişen kısıtlamalardan çoğu zaman muaftır ve böylece tasarımcıya daha geniş bir yaratıcı özgürlük alanı sağlamaktadır (Jodidio, 2011, s. 8). Geçici yapıların tasarımında, güncel yapım teknolojileri, yenilikçi strüktür ve malzeme kullanımı ve bu bağlamda üretilen biçimlerle birlikte, göreceli olarak daha küçük ölçekli yapılarda daha kısa süreli kullanımların mimarın yaratıcı özgürlük alanını destekleyen unsurlar olduğu söylenebilir. Dolayısıyla, geçici yapılar mimari tasarım için bir bakıma bir araştırma, deneme ortamı olmakla birlikte potansiyel bir ilham kaynağı olarak da görülebilir. Bu kapsamda geçici mimari yapıların karakteristik özelliklerinin belirlenmesinin mimari tasarım alanına yeni bir bakış açısı getireceği düşünülmektedir. 


\subsection{Metot}

Geçici mimari yapıların karakteristik özelliklerini belirleyebilmek için öncelikle bir mimari yapının karakteristiğini belirleyen temel unsurların tanımlanmasına gerek olduğu düşünülmektedir. Bu sayede bir mimari yapı türü olarak geçici yapıların benzer unsurlara sahip olduğu düşüncesiyle, bu unsurlar aracılığıyla ölçülebilir, gözle görülür ve deneyimlenebilen karakteristiğinin tanımlanabileceği öngörülmektedir. İlk mimarlık teorisyeni olarak Vitruvius, iyi bir mimarlığın üç temel özelliğini sağlamlık, uygunluk ve güzellik olarak tanımlamıştır. Bu tanımlamadan yola çıkarak mimari bir yapıyı tanımlayan ve biçimlendiren özellikler çalışma kapsamında; sağlamlıkla ilgili olarak strüktür, güzellikle ilgili olarak malzeme ve biçim, uygunlukla ilgili olarak işlev ve bağlam kavramları dikkate alınarak tanımlanmaya çalışılmıştır.

\subsubsection{Strüktür}

Tasarlanan her yapı formunun ayakta durabilmesi için strüktüre ihtiyaç vardır (Kavurmacıoğlu ve Arıdağ, 2013, s. 59). Strüktür, mimaride biçimi belirleyen unsurlardan biri olarak öne çıkar. Özellikle teknolojinin de etkisiyle gelişen strüktür tasarımı mimaride yeni biçimlerin elde edilmesini sağlamıştır. Taşkın (2019)'a göre strüktür sisteminin, mimariyle ilişkisinde mekânın işlerliği ve biçimsel özellikleri etkin rol oynar. Yaşantının değişmesi ve çeşitlenmesi zaman içinde yeni mekân kullanımlarını tanımlamış, paralelinde oluşan yeni yapı tiplerini inşa edebilmek için farklı strüktür sistemlerine ihtiyaç duyulmuştur. Bu durum, gelişen teknolojinin de yardımıyla, strüktür sistemlerinin gelişimini ve değişimini beraber getirmiştir (Taşkın, 2019, s. 24). Pekin Ulusal Stadyumu örneğinde, yenilikçi strüktür tasarımının biçimi belirlemedeki etkisi görülebilir (Şekil 4.a).

\subsubsection{Biçim}

Yapılar, tasarımcının koşulları ve amaçları yönünde belirli ölçekte hacim kazanıp biçimlenmektedir. Biçimi belirleyen özellikler; zaman ve teknoloji, mekân kullanımı ve işlev, bağlam ve konum, iklimsel ve çevresel koşullarla birlikte mimari elemanlar arasındaki ilişki düzeni ve ekonomik olanaklar şeklinde sıralanabilir (Aksoy, 1977, s. 20). Mimari biçim, tasarım pratiği bakımından şekil, boyut, renk, doku, konum, yönelim ve görsel özelliklerden oluşur. Bu yönüyle mimari biçim, genel olarak ve öncelikle şekil özellikleriyle birlikte kütlesel olarak anlaşılmaktadır (Charleson, 2006, s. 19). Gwathmey'in tasarladığı konut örneğinde küp şeklindeki temel formda boşluklar açılarak, farklı nitelikte alanlar elde edilmiş, biçim doluluk ve boşlukların hareketiyle oluşturulmuştur (Şekil 4.b).

\subsubsection{Malzeme}

Mimaride düşüncenin aktarılmasında önemli bir etkiye sahip olan malzeme, tasarım fikrinin bir parçası olarak yapının sağlamlık, geçirgenlik, güzellik gibi anlamsal, doku ve renk gibi algılanan fiziksel özelliklerini ifade edebilir (Brawne, 2003, s. 125). Her malzemenin sınırları ve olanakları bulunmaktadır. Malzemelerin boyutu, doğal veya yapay koşullarla belirlenebilir ve binaların nihai boyutlarını ve biçimini etkileyebilir (Conway ve Roenisch, 1994, s. 111). Malzemenin kullanımınınsa yapının işleviyle ilişkili olarak belirlenmesinin yanında yapının niteliği, kullanımı, kullanım periyodu ya da süresi malzemeyi etkiler. Nitekim bir savunma yapısının dayanıksız, bir çadırın da kırılgan bir malzemeden yapılması beklenemez. Malzemenin biçime etkisi bakımından en çarpıcı örneklerden biri İspanya Bilbao'da bulunan Guggenheim Müzesidir (Şekil 4.c).

\subsection{4 İşlev}

İnsanın var olma çabası ve bu amaçla çevreye uyum gayreti, insanın çevresiyle karşılıklı etkileşimini gerektirmektedir. Bu etkileşimden doğan işlev (Aksoy, 1977, s. 18) kimi zaman bir intiyacı işaret ederken kimi zaman da bir mekânın ya da yapının kullanım amacını ifade eder. İşlevin mimarinin ana unsurlarından biri hatta mimari tasarımın 
gerekli koşulu olduğu söylenebilir. Bu bakımdan işlev yapının belirli özelliklerinin belirleyicisi ve bu bakımdan da tanımlayıcısı olur (Salvan, 1999, s. 152). İşlev odağa alındığında, kullanımlar zamanla değişebilir, dönüşebilir, çeşitlenip yok olabilir. Ancak işlevin mimarinin belirleyici bir öge olması durumu kalıcı bir şekilde varlığını sürdürür. Cephesi görsel olarak geçirimsiz, opak olan bir yapı bir müzeyi, tümüyle şeffaf cam cephe bir ofis binasını işaret edebilir (Şekil 4.d).

\subsubsection{Bağlam}

Bağlam, yapının içinde yer aldığı ve tasarımı etkileyen çevresel koşullarla birlikte sosyal, kültürel, ekonomik, teknolojik ve diğer fiziksel koşullar olarak tanımlanabilir (Erman ve Yılmaz, 2017, s. 101). Mimari yapı, her zaman bir bağlam içinde yer alır ve bağlama ait unsurlardan beslenerek biçimlenir. Bu bakımdan bağlam, yapının içinde bulunduğu çevreye tutunması için bir araç olarak ortaya çıkmaktadır (Erman ve Yılmaz, 2017, s. 107), (Şekil 4.e).

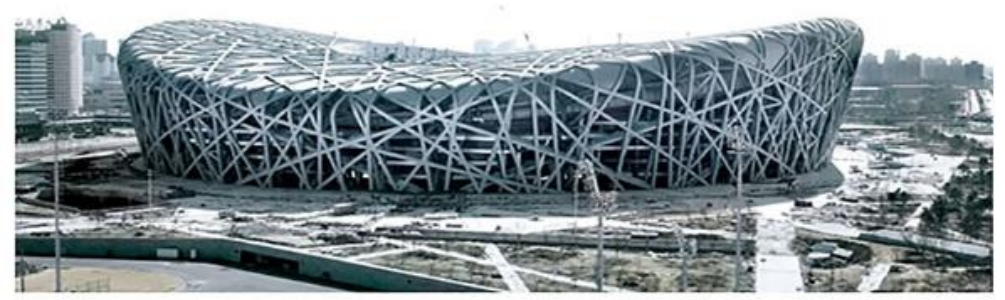

(a)

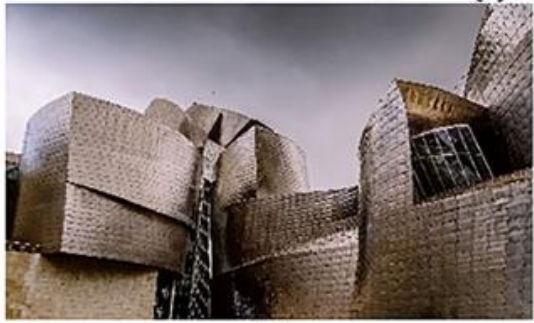

(c)

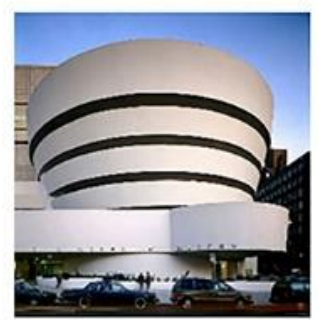

(d)

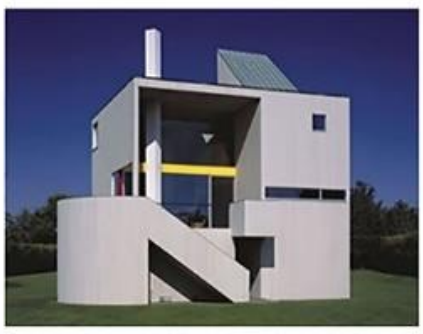

(b)

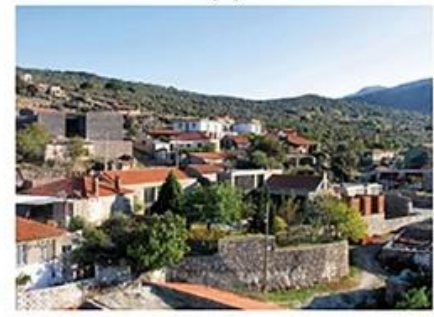

(e)

Şekil 4. a)Pekin Ulusal Stadyumu, A. Weiwei, J. Herzog, P. Meuron, L. Xinggang, 2008, (URL-

6), b) Gwathmey Konutu, C. Gwathmey, 1967, (URL-7), c) Guggenheim Müzesi Bilbao, F.

Gehry, 1997, (URL-8), d) Guggenheim Müzesi, F. L. Wright, 1959, (URL-9), e) Yahşıbey Evleri, N. Sayın, 2011, (URL-10).

Açıklanan bu kavramlar ışı̆̆ında,

- Strüktür kapsamında geçici yapılarda kullanılan taşıyıcı türleri, tasarım yaklaşımı ve strüktürün sağladığı taşınabilme, sökülebilme olanağı,

- Biçim açısından plan geometrisi ve şemasıyla birlikte kütle karakteri, kütle formunun geometrik soyutlanması yapılarak biçim özellikleri,

- Malzeme kapsamında geçici yapının işlevsel ve biçimsel karakterine bağlı olarak kullanılan malzemelerle olan ilişkisi ve malzeme özellikleri,

- İşlev bakımından geçici yapının kullanım amacı, yapının tekli ya da çoklu kullanım durumu,

- Bağlam konusunda ise geçici yapının bulunduğu yer ve çevresel koşullarla olan ilişkisi değerlendirilmeye çalışılmıştır.

Bütün bunlara ek olarak yapının geçici olma durumunda önemli bir ölçüt olan kullanım süresine ilişkin tespitler de değerlendirmeye dâhil edilmiştir. 


\subsection{Materyal}

Çalışmanın materyalini Endüstri Devrimiyle ilk örnekleri görülmeye başlanan 1900-2020 yılları arası 100 yılı aşkın bir süre içinde inşa edilmiş geçici yapı örnekleri oluşturmaktadır. Bu uzun zaman dilimi 1900-1940, 1950-1970, 1980-2000 ve 2000-2021 yılları arası olmak üzere dört döneme ayrılmış, her dönemden ikişer tane olmak üzere sekiz adet yapı incelenmiştir. Geçici yapı örneklerinin seçiminde inşa edildiği dönemin genel karakterini yansıtan ve sonraki dönemlerde inşa edilecek geçici mimarlık örneklerine öncülük ettiği düşünülen yapılar tercih edilmiştir. Belirlenmiş olan beş unsur yardımıyla, geçici yapıların sahip olduğu mimari karakter tanımlanmaya ve farklı dönem örnekleriyle biçim, işlev, strüktür, malzeme ve bağlamla ilintili değişimler irdelenmeye çalışıımıştır.

\section{Bulgular}

\subsection{0-1940 Yılları arasında inşa edilmiş geçici yapıların değerlendirilmesi 3.1.1. Yeni ruh pavilyonu, Le Corbusier, 1925}

L'Esprit Nouveau (Yeni Ruh) pavilyonu, Paris'te Uluslararası Dekoratif Sanatlar Sergisi için inşa edilmiş bir model evdir. Pavilyon, endüstriyel olarak üretilen malzemelerle evin standartlaştırma potansiyelini ve öngörülen çağdaş yaşam biçimini sergilemek için tasarlanmıştır. Yapı, iç mekânda bir sergileme görevi görse de kendini sergileyen mimari bir elemandır (Yıldııım, 2009, s. 60). Sergilenen bu model ev aracılığıyla sunulan yaşam deneyimini toplum bu mimari gelişmeyi deneyimleyebilmektedir. Pavilyonun bir ağacı yapının içine dâhil etmesi, bağlamla kurduğu ilişki ve tasarımda doğaya olan saygının ve barışçıl yönün bir göstergesi olarak yorumlanabilir. 1925 yılı Nisan-Ekim aylarında süren fuarın ardından yapı 1926'da yıkılmıştır. Pavilyon, 1977'de İtalya'nın Bologna kentinde yeniden inşa edilmiştir (URL-11).

Pavilyonun karakteristik özellikleri incelendiğinde plan şemasının kapalı ve yarı açık mekânlardan oluştuğu görülür. Plan geometrisi, kare ve dairesel parçalara sahiptir. Formu oldukça sade ve sınırlarını oluşturan çizgileri nettir. Strüktür olarak betonarme tercih edilmiş dolayısıyla yapının strüktürü kullanıcı tarafından görünmemektedir. Malzeme kullanımında opaklığın ve şeffaflığın etkisi bir arada görülmektedir. Bu sebeple yarı kapalı ve yarı açık cephe kullanımı söz konusudur. Kültürel amaçlı kullanılan yapıya tekli işlevin yüklendiği görülmektedir. Yapının bağlamı, yeşil ile kaplı bir fuar alanıdır ve geçicilik süresi fuar boyunca 7 aydır (Şekil 5).

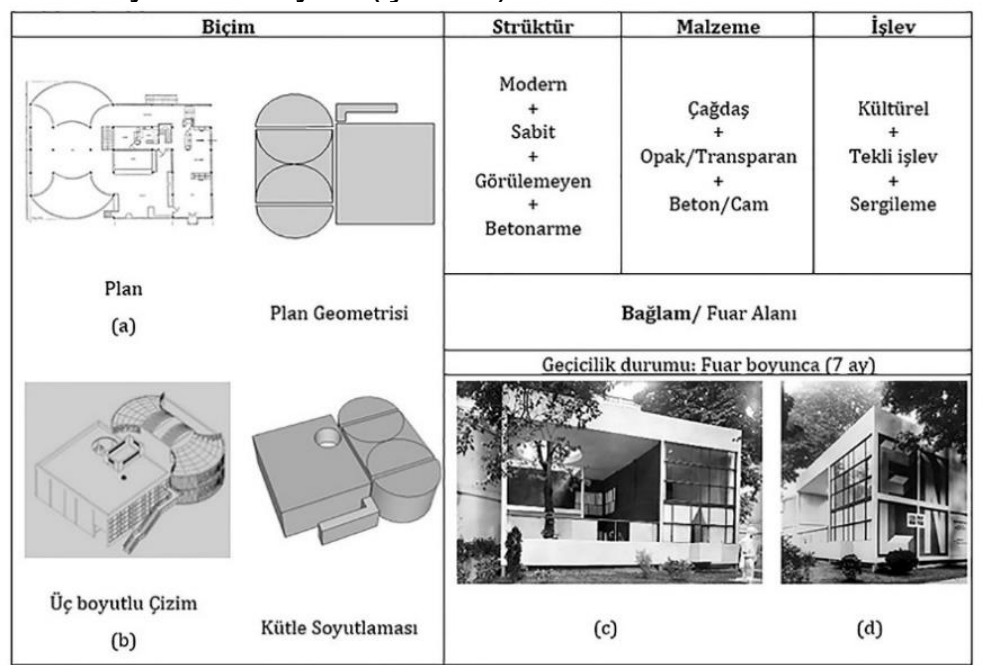

Şekil 5. I'Esprit Nouveau (Yeni Ruh) Pavilyonu Karakteristik Özellikleri a- d: Sdegno vd., 2017, b: URL-12, c: URL-11). 


\subsubsection{Yeni zamanlar pavilyonu, Le Corbusier, 1937}

Pavilion of New Times (Yeni Zamanlar Pavilyonu) Paris'teki 1937 Dünya Fuarı için inşa edilmiştir. Çelik strüktürle inşa edilmiş, tekstil malzeme kullanılarak biçimlendirilen yapı adeta dev bir çadıı andırmaktadır. Halka açık toplantılar, konferanslar, sinema, tiyatro gibi etkinlikler için kullanılan pavilyonun fuar sonrası sökülüp Fransa'nın farklı şehirlerine taşınması amaçlanmıştır (Naegele, 2003, s.41). Bu örnekte geçici olarak kullanımı önerilen bir yapının hafiflik, geçirgenlik ve taşınabilirlik gibi kavramların tasarıma dâhil olduğu görülmektedir.

Pavilyonun karakteristik özellikleri incelendiğinde plan geometrisi basit bir dikdörtgen ile oluşturulurken, yapı biçimi, basit küpün deforme edilmesiyle oluşmuştur. Yapı, çelik direkler, kablolar ve borularla oluşmuş hafif strüktürle desteklenen devasa bir çadır formundadır. Geçici yapının, çelik strüktürünü tümüyle kaplayan tekstil malzeme, çadır imgesini kuvvetlendirerek yapıyı daha hafif hissettirmektedir. Sergileme amacılla tasarlanan yapı, esnek kullanım olanaklarıyla toplantı, sinema, sunum, dinleti gibi kültürel amaçlı birçok işleve cevap verebilecek niteliktedir. Yapının bağlamını, ağaçlarla çevrili bir fuar alanı tanımlar. Yapının geçicilik süresi fuar boyunca 6 aydır (Şekil 6 ).

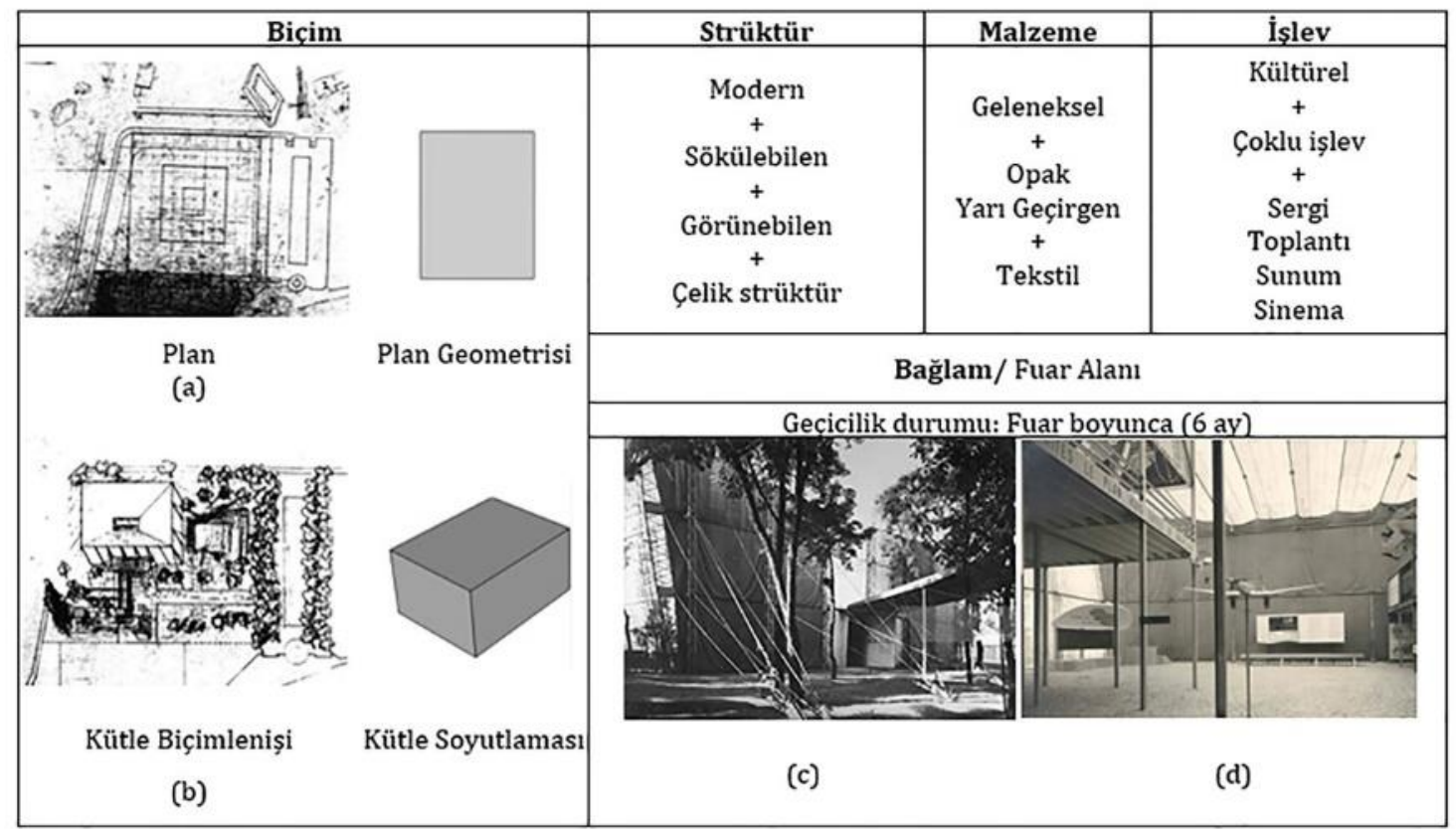

Şekil 6. Pavilion of New Times (Yeni Zamanlar Pavilyonu) Karakteristik Özellikleri a- b: Udovicki-Selb, 1995, c-d: URL-11).

20. yüzyılın ilk iki çeyreği, geçici yapıların karakteristik özelliklerinin temelinin atıldığı dönemdir. Bu dönemle birlikte beliren mekânsal denemeler, bir sonraki dönemde görülecek geçici yapılar için yol gösterici olmuştur.

Modern dönemden aldığı ışığı yansıtan geçici tasarımlarda döneme uygun sadelikte, temel geometrik formlarla ulaşılan insan ölçeğinde tek katlı biçimler hâkimdir. Bu dönemde çağın teknolojisi kullanılsa da ileriki dönemlere göre nispeten teknolojinin geri planda kaldığı söylenebilir. Bu dönem pavilyonları yeni mekân ve biçim denemelerini sunmak için tasarlanmıştır ve bu amaçla daha çok sergileme olarak tanımlanabilecek, tekil işleve sahiptirler. Örneklerde dönemin ruhuna uygun biçim karakterinin yanında, beton, çelik, cam ve tekstil gibi çağın teknolojik malzemelerinin ve yapım tekniklerinin kullanıldığı görülmektedir. 


\subsection{0-1970 Yılları arasında inşa edilmiş geçici yapıların değerlendirilmesi}

\subsubsection{Türkiye pavilyonu, Utarit İzgi, Muhlis Türkmen, İlhan Türegün ve Hamdi Şensoy, 1958}

II. Dünya Savaşı'ndan sonra Belçika'da gerçekleştirilmiş ilk önemli Dünya Fuarı olan EXPO'58 için inşa edilmiştir. Geometrik form kullanımı, strüktürün okutulması, çelik strüktür ile camın birlikteliği ve şeffafılı ön plandadır (Altun, 2003, s.75). Yapıda, modüler bölmeler ve prefabrike yapı elemanları kullanılmıştır. Prefabrike yapım sistemi, sökülüp takılabilir niteliktedir böylece fuar bitiminde yapı, çeşitli yerlere taşınarak kullanıımıştır (Ülkü, 2019, s.507, 512). Pavilyonun yapısı, yüksüz taşıyıcı modüler panellerden yapılmış bir dış duvar (giydirme cephe), sergi salonu için cam plaka ve alüminyum, restoran için ise yapısal çelik konstrüksiyonla desteklenen ahşaptır (Bozdoğan'dan aktaran, Bancı, 2009, s.53). Hacimler arasındaki ilişki, mekânların hem sürekliliğini hem de akışını özgürce göstermektedir (Bancı, 2009, s.67).

Pavilyonun plan geometrisi, kare ve dikdörtgenden oluşan iki kütle halinde parçalı bir yapıdan oluşmaktadır. Her kütleye tanımlanan farklı işlevler cephede değişen malzeme kullanımıyla ifade edilmiştir. Strüktürde yeni bir teknik olarak modüler yapım sistemi kullanılmıştır. Uygulanan strüktür, kullanıcı tarafından görülebilmektedir. Yapının bağlamı, fuar alanıdır ve geçicilik süresi fuar boyunca 6 aydır (Şekil 7).

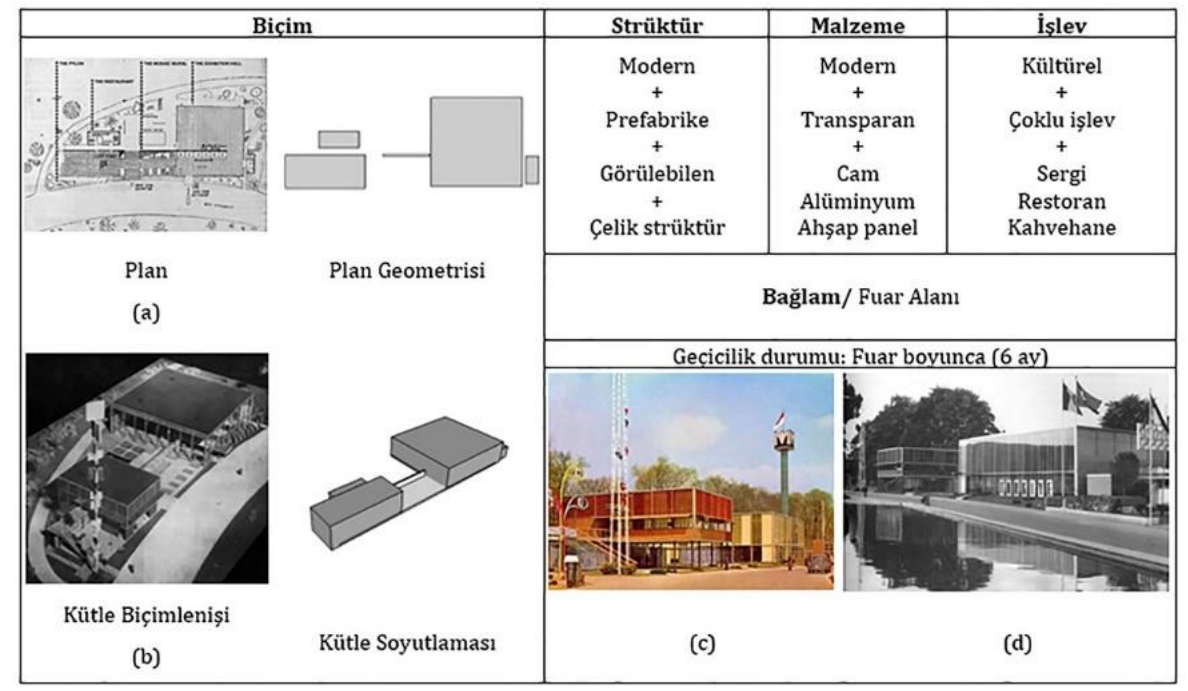

Şekil 7. Türkiye Pavilyonu Karakteristik Özellikleri (a-b-c-d: Kan Ülkü, 2019 s.506-510).

\subsubsection{Biosphere montreal (Biyosfer), Buckminster Fuller, 1967}

Montreal (Biyosfer) Pavilyonu 1967 yılı nisan ve ekim ayları arasında gerçekleşen EXPO'67 Dünya Fuarı için inşa edilmiştir. Temel biçimin jeodezik kubbeyle oluşturulduğu yapıda malzeme verimliliği, yapısal bütünlük ve modüler tasarım konusunda ilgi çekici bir mimari çözüm önerilmiştir. Yapısal çözümlemede üçgenlerle sağlanan kombinasyon sayesinde maksimum verimlilik sağlanmıştır (URL-13). Modüler yapı bileşenleri sürdürülebilir, kolayca tekrarlanabilir strüktür sisteminin, düşey taşıyıcıya gerek olmaksızın oluşan kubbenin sağladığı geniş hacimde çeşitli programları içeren farklı temalardaki altı adet kat düzlemiyle biçimlendirilmiştir.

Çelik boruların birleşim noktalarından kaynaklanarak eklemlenmesiyle oluşturulan 20 yüzlü eşkenar üçgen birimlerle oluşturulan kafes tipi yapı, akrilik paneller ile kaplanmıştır. Böylece 76 metre çapında, 62 metre yüksekliğindeki kubbenin içinde yer alan hacimlere gelen ışık miktarı ve ısı kontrol edilmeye çalışıımıştır. 1976 yılında çıkan bir yangında yapıyı çevreleyen akrilik panellerin büyük bir kısmı yanmasının ardından kubbenin kaplaması yenilenmemiştir. Mevcut yapısal çıplaklığı, tasarımı ortaya çıkaran, strüktürü 
okunabilir kılan bir şeffaflık yaratmaktadır. Yapı, 1990 senesinde ise Kanada Hükümeti tarafından satın alınarak ekolojik müze olarak kullanılmaya başlanmıştır (URL-14).

Dairesel plan geometrisine sahip olan pavilyonun formu üçgen parçalardan oluşan küre biçimindedir. Yapı, çelik strüktürden oluşan modüler bir tasarımdır. Yapının üstlendiği işlev sergi olmakla birlikte tekildir. Ayrıca strüktür jeodezik kubbe formunda kolaylıkla okunabilmektedir. Yapının bağlamı, fuar alanıdır ve geçicilik süresi fuar boyunca 6 aydır (Şekil 8).

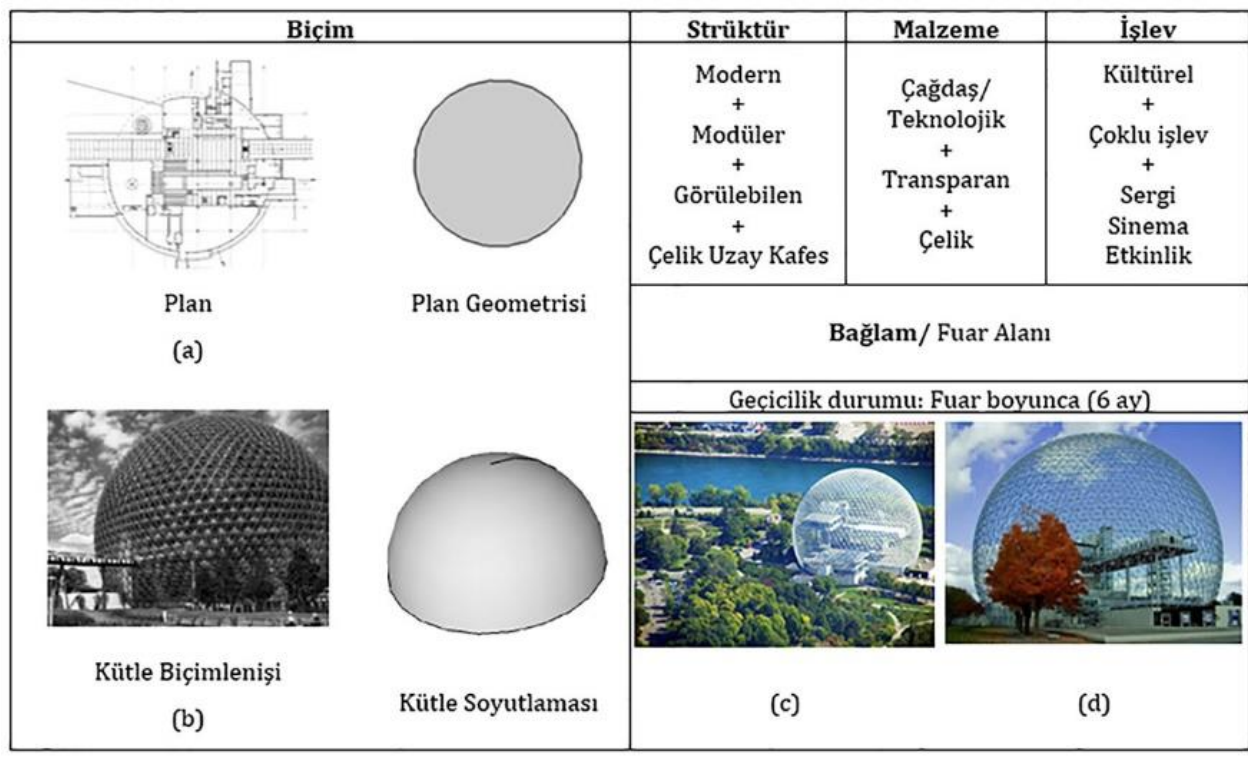

Şekil 8. Montreal Biosphere (Biyosfer) Pavilyonu Karakteristik Özellikleri (a: URL-3, b-c-d: URL15).

1950-1970 yılı örneklerinde geçici yapıların biçimlenişinde strüktür tasarımının ve modül kullanımının ön plana çıktığı görülmektedir. Modüler tasarım yaklaşımında prefabrik yapı elemanlarının kullanılması yapının inşasında ve sökümünde büyük kolaylık ve hız kazandırmıştır. Dönemin teknolojik gelişmeleri ile birlikte yenilikçi mekân kullanımına ve kalitesine vurgu yapan farklı plan çözümleri ile yapının sahip olduğu mekân içi kullanımın öneminin gittikçe arttığı söylenebilir. Bu dönemde geçici yapıların sergileme işlevi sürse de mekân tasarımında çeşitli aktivitelerin yer aldığı ve kullanıcının aktif rol oynadığı mekân kullanımının geliştiği görülmektedir. Böylece geçici yapılar pasif sergileme alanı olmaktan çok sosyal yaşamı etkileyen aktif bir alan olmaya başlamıştır.

\subsection{0-2000 Yılları arasında inşa edilmiş geçici yapıların değerlendirilmesi}

\subsubsection{IBM padiglione itinerante (IBM gezici pavilyonu), Renzo Piano, 1984-1986}

IBM Gezici Pavilyonu (IBM Padiglione Itinerante) bilgisayar teknolojisindeki gelişmeleri teşvik etmek ve sergilemek amacıyla tasarlanmıştır. Bu geçici yapı, Lyon, Londra, Roma, Milano dâhil olmak üzere 20 Avrupa şehrinin her birinde bir ay boyunca sergilenmiş ve ardından sökülmüştür. Yeni bilgi teknoloji araçlarının sergilendiği, kent parklarında yeşil alanlara yerleştirilen pavilyon, destek elemanları ile yükseltilmiş bir platform üzerinde oturan şeffaf bir tünel biçimindedir. Kolay taşınabilen, monte ve demonte edilebilen yapı tekrarlayan ahşap modüller ve ısıyla şekillendirilmiş polikarbon elemanlarla biçimlendirilmiştir (URL-17). Modüllerin her biri, iki sıra ahşap kemer üzerine yerleştirilmiş bir sıra polikarbon piramit ve bu piramitlerin tepelerini birbirine bağlayan ahşap kemerlerden oluşmuştur. Pavilyonun iç mekânında elektronik ekipmanların doğru çalışmasını sağlamak ve kullanıcı için rahat bir ortam yaratmak için ortamdaki sıcaklık ve nem dengesi sağlanmaya çalışılmıştır. Pavilyonun strüktürünü oluşturan ahşap ve alüminyum malzemeler, ziyaretçiyi dokunmaya davet eden dokunsal bir yapıya sahiptir. 
Ahşap ve biyomorfik şekiller yalnızca organiklik ile kalmaz aynı zamanda yapının yemyeşil ortamlarda daha evde gibi görünmesine yardımcı olmaktadır. Bu, kendini doğaya taklit eden ve kendisini doğaya yerleştiren teknolojinin idealini açıkça ifade eden bir tasarımdır (URL-18). 1986 yılında serginin tamamlanmasının ardından kalıcı olarak sökülen pavilyon, yeniden birleştirilmemiştir.

Pavilyonun karakteristik özellikleri incelendiğinde plan geometrisi, lineer dikdörtgen bir şemaya sahip iken kütle formu, yarı silindir biçimindedir. Modüllerde malzeme kullanımı, geleneksel ve modern yaklaşımın bir sonucudur. Yapı, sergileme görevinden dolayı tek işlevlidir. Cephe, tümüyle transparan bir görünüme sahiptir. Dolayısıyla dışarısı ile içerisi arasındaki görsel ilişki kesilmemektedir. Yapının yerleşiminde bağlam olarak şehir parkları yani kamusal alanlar tercih edilmiştir geçicilik süresi sergi süresince 1 aydır (Şekil 9).

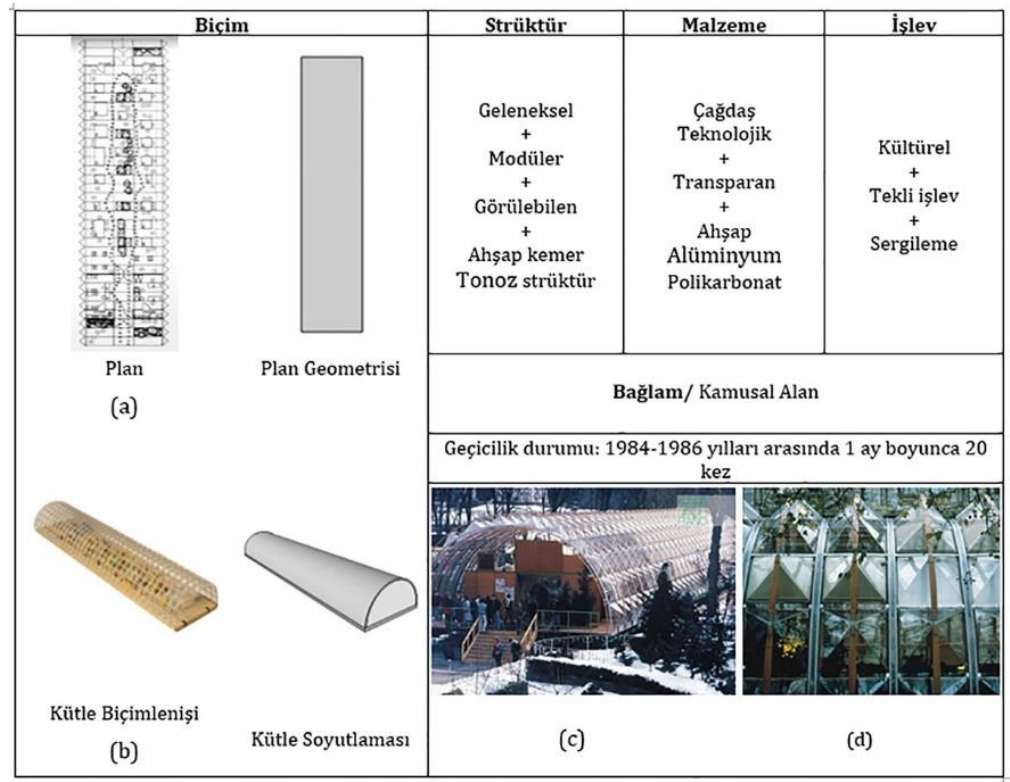

Şekil 9. IBM Gezici Pavilyonu Karakteristik Özellikleri (a: URL-16, b-c-d: URL-17)

\subsubsection{Cardiff körfezi ziyaretçi merkezi, Will Alsop, 1990}

Cardiff Körfezinin yenilenmesi için yapılan çalışmaları sunmak ve ziyaretçileri bilgilendirmek için inşa edilen ziyaretçi merkezi, Cardiff şehrinin liman bölgesinde yer almaktadır. Düşük bir maliyetle inşa edilen bu geçici yapı, oval formda, basit, heykelsi, çağdaş ve işlevseldir. Oval çemberler şeklindeki çelik strüktürün sıralı dizisiyle elde edilen tüp biçimi, üçgen biçim oluşturan çelik taşıyıcı desteklerle taşınır. Zeminden böylece yükseltilen yapının her iki ucu, denize veya karaya doğru bakış sağlar şekilde tamamen şeffaftır. Oval çelik strüktürün yarattığı boşluklar ahşap kontrplaklarla kapatılmış, yapının hava şartlarına daha dayanıklı olması içinse PVC kaplı bir tekstil malzemeyle kaplanmıştır. Yapının çeperlerini oluşturan ahşap kaplamalarda açılan amorf şekilli küçük yırtıklarla iç mekânda aydınlık ve ışık hareketleri sağlanmıştır. Dönemi için etkileyici bir mimariye sahip olan yapı, adeta kentsel bir heykel gibi biçimlenmiştir. İnşa edildiği noktadan 1993-94 yıllarında yakınlardaki başka bir yere taşınan geçici yapı başlangıçta beş yıl kullanılacak şekilde tasarlanmış, fakat daha uzun süre kullanımdan sonra 2010 yılında sökülerek kaldırılmıştır (URL-19).

Plan geometrisi basit bir dikdörtgenden oluşan yapı, sergileme işlevi kapsamında tanıtım merkezi amacıyla inşa edilmiş olup tekli işleve sahiptir. Yapının bağlamı, şehrin eski bir liman bölgesidir ve geçicilik süresi bölgenin gelişimi boyunca beş yıldır (Şekil 10). 


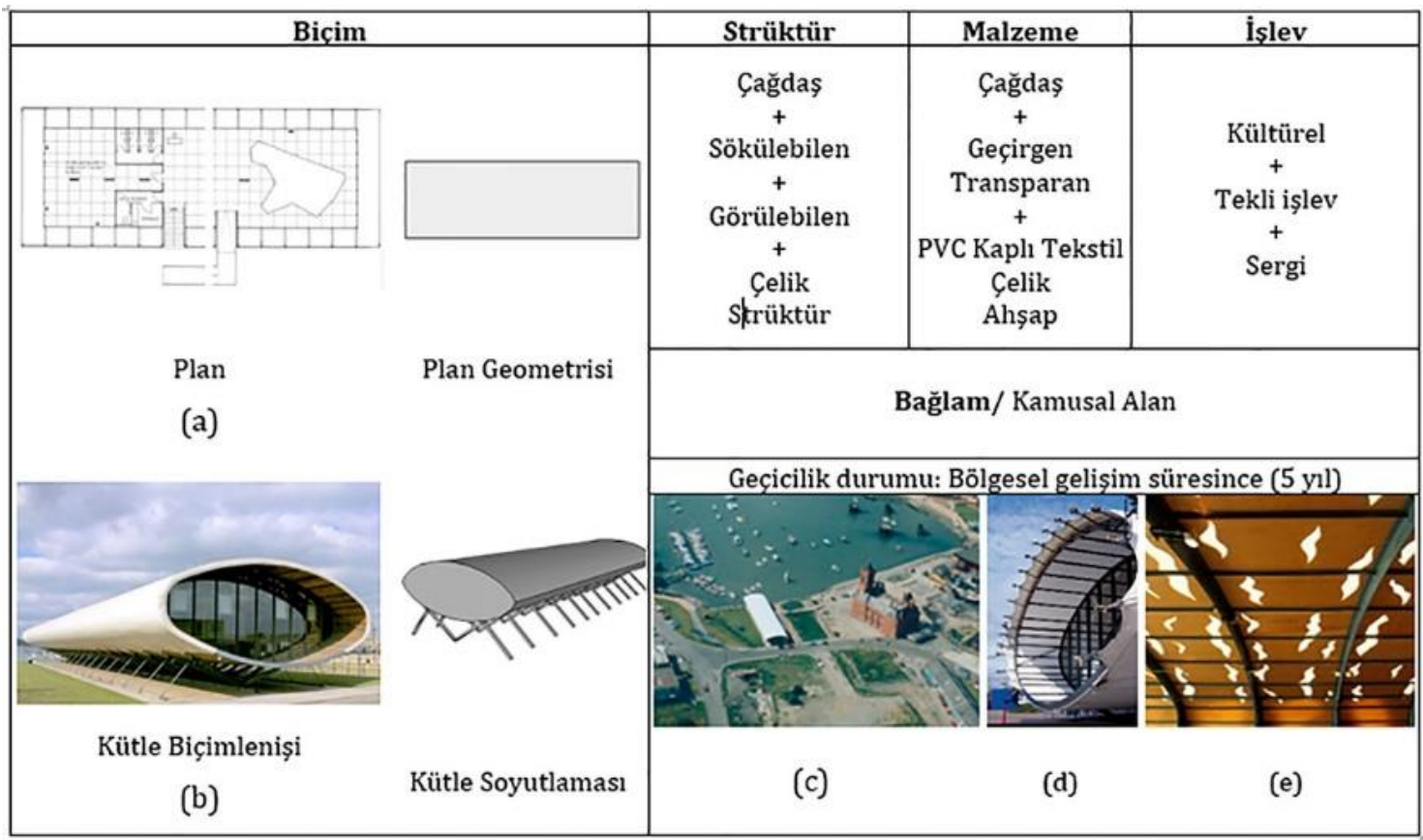

Şekil 10. Cardiff Körfezi Ziyaretçi Merkezi Karakteristik Özellikleri (a: URL-21, b: URL-20, c- de: URL-19).

Teknolojik gelişmeler ve ardından bilgisayar çağının başlaması ile birlikte yaşanan gelişme, geçici yapıları da etkilemiştir. Geçici yapıya ait parçaların takılıp sökülebilme durumu önceki zamanlara göre sıklaşmış ve yapıların dinamik bir etkiyle biçimlenmesini sağlamıştır. Bu dönemde geçici yapıların yer aldığı bağlam konusunda değişikliklerin görüldüğü söylenebilir. Fuar etkinliğinin dışında özgün kullanımlar için tasarlanan geçici yapıların görülmeye başlanması, bağlam açısından yapının sınırlarının genişlediğini ve böylece yapının işlevsel alanının genişleyerek yaygınlaşmaya başladığı söylenebilir. Bu bakımdan geçici yapılar kamusal alanda daha çok yer almaya başlamıştır.

\subsection{0-2020 Yılları arasında inşa edilmiş geçici yapıların değerlendirilmesi 3.4.1. Mutfak anıtı (Das Küchenmonument), Raumlabor-Berlin, 2006}

2006 yılında Almanya'da hayata geçirilen yapı, meydanların, sokak ve avluların ötesinde davetkâr olmayan köprü altı, tünel, endüstriyel alanlar gibi unutulan kentsel mekânların aktivasyonu üzerine tasarlanan önemli bir projedir. Tasarım çelik ızgaralı bir rampa ile girişi yapan kutu ve kabarcık olarak adlandırılan ana mekân olarak iki bölümden oluşmaktadır. Girişe ek olarak, kutu, yapıda kabarcığı sürekli hava ile besleyen vantilatörlerin olduğu pnömatik sistemi içerir. Kabarcığın amorf ve esnek yapısı içinde yer aldığı kamusal alanın biçimine uyabilir ve intiyaca göre kullanılabilir. Bu bakımdan yapının plan geometrisi, malzeme ve esnekliğin etkisiyle organik bir forma sahiptir. Mahalle toplantıları, film gösterimleri, partiler, yemek pişirme etkinlikleri, boks müsabakaları ve buhar banyosu gibi birbiriyle ilişkisiz pek çok işleve ev sahipliği yapan strüktür, geleneksel kentsel mekân algısının sınırlarını genişleterek farklı bir kentsel yaşamın ve kentsel mekânın mümkün olabileceğini göstermektedir. Özellikle kurulduğu alana uyum sağlayarak yayılan, daha büyük ya da daha küçük olabilen yapı göz ardı edilen kentsel alanların canlandırılması için bir uyaran etkisi yaratmaktadır. Adaptasyon ve uyum potansiyeli yüksek olan kabarcık, PVC malzemenin biçimsel esnekliğin yanında sağladığı şeffaflıkla içeri ve dışarı etkileşimine görsel olarak izin vermektedir. Mutfak anıtı, 3 gün süreyle kullanılmaktadır (URL-22) (Şekil 11). 


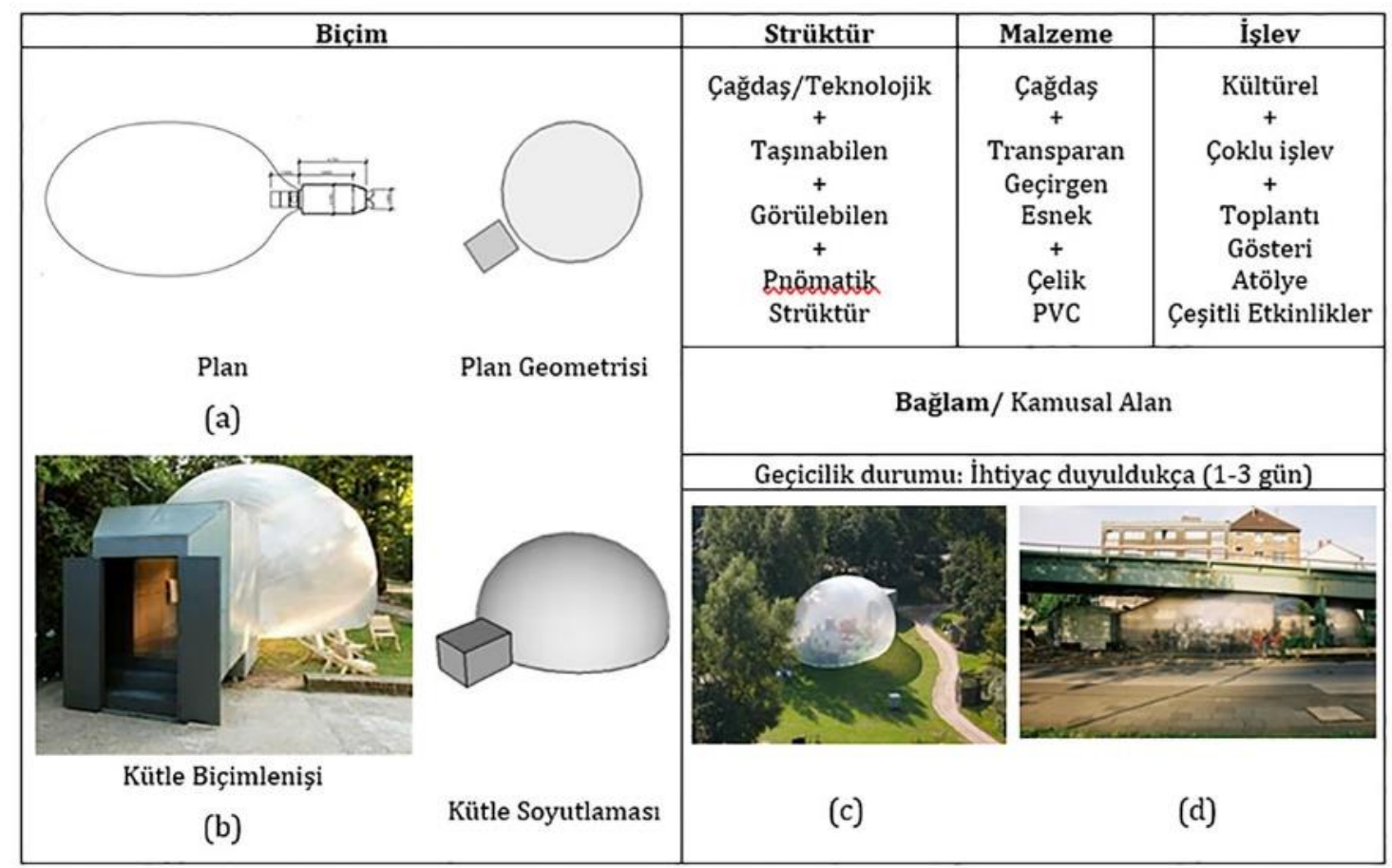

Şekil 11. Mutfak Anıtı (Das Küchenmonument) Karakteristik Özellikleri (a-b, d: URL-24, c: URL23).

\subsubsection{Serpentine pavilyonu, Selgas Cano, 2015}

Serpentine Gallery'nin bahçesinde 2000'li yıllardan itibaren her yıl bir tema çerçevesinde farklı bir mimar tarafından tasalanmış pavilyon inşa edilerek dört ay süreyle sergilemeye sunulmaktadır. Örnek pavilyon ise Londra'da yeraltının çok katmanlı ve hareketli kaotik ağından esinlenerek, ana mekâna erişimi sağlayan adeta gizli koridorlarla biçimlendirilmiştir. Pavilyonun merkezinde farklı yönlere uzanan dört mekânla birlikte toplantı ve kafe alanı bulunmaktadır. Pavilyon, dinamik biçime sahip mekânlar sayesinde performans, müzik, film ve dans gibi farklı etkinlikler için kullanılabilmektedir. Pavilyon kütlesi bir dizi çelik kemerin etrafına sarılmış, poligonal formda panellerle yapıyı saran çeşitli renklerde çift katmanlı bir plastik kaplamayla oluşturulmuştur. Kaplama malzemesi, çevre dostu, biyolojik çözünürlüğe sahip yarı saydam ve flor bazlı çok renkli polimer (ETFE) esaslı plastik malzemedir (URL-16). Geçirgen özellikteki renkli malzeme sayesinde, iç mekânda renklerle oluşan bir aydınlık mekân deneyimlenmektedir. Yapının kaplama yüzeyi kimi kısımlarda şeffaf, kimi kısımlarda opaktır. Böylece mekânda şeffaflık, gölgeler, hafiflik, değişim, sürpriz, ışık ve renk olgusu öne çıkarken, malzeme ve strüktürün olanakları ve görsel etkisi pavilyona hareketli ve hafif bir görünüm kazandırmaktadır.

Organik bir forma sahip olan pavilyonun çeşitli kültürel etkinlikler için kullanılabilmekte, görsel çekiciliğiyle gündüz ve gece canlı kalmaktadır. Pavilyonun bağlamı, ağaçlarla çevrili bir kamusal açık rekreasyon olup geçicilik süresi bir yıl için yaz boyunca dört aydır (Şekil 12). 


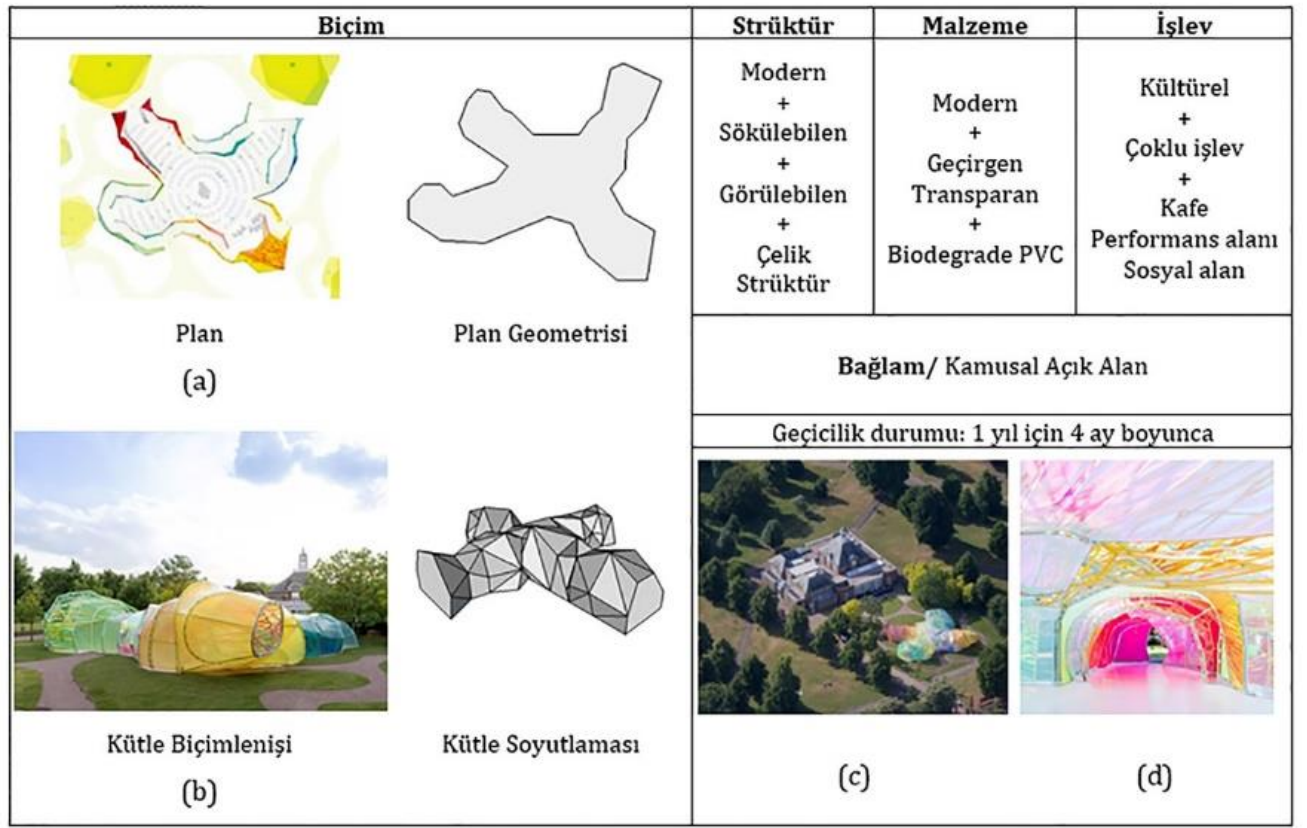

Şekil 12. Serpentine Pavilyonu Karakteristik Özellikleri (a: URL-25, 2015, b- c: URL-26, d: URL27).

2000 sonrası yıllarda geçici yapıların kullanım amacının, bağlamının, içerdiği işlevlerin ve kullanıcı kitlesinin önceki dönemlere göre değiştiği tespit edilmiştir. Bu durumu yaratan en önemli sebebin yapının artık daha çok kamusal alanın içine girmesi, kentin ve kent yaşamının parçası olmaya başlaması olduğu düşünülmektedir. Kentler, her yaştan, cinsiyetten, dinden, kültürden insanın yaşadığı toplumsal bir modeldir. Dolayısıyla geçici yapılar, günümüz kentlerinde kamusal alanlarda gerek kullanıcı, intiyaç, işlev gibi farklılıkları barındıracak, farklııklara olanak tanıyacak ve temsil edebilecek mekânlar haline gelmiştir.

Bu dönemin en karakteristik özelliğinin, geçici yapılar sayesinde kentlerin kamusal alanda yeniden yapılanmasının ve canlanmasının olduğu söylenebilir. Kent için potansiyele sahip fakat göz ardı edilmiş kentsel mekânların veya farklı sebeplerden dolayı kullanıcılar için artık cazip bulunmayan alanların kent yaşamına dâhil olması sağlanmıştır. Böylece geçici yapılar kentlerin ve kent mekânının yeniden keşfi için bir araç olmuştur. Bu açıdan bakıldığında geçici yapıların canlı ve değişken varlığıyla kalıcı olmaya meydan okuduğu söylenebilir. Geçici yapıların özellikle 2000'li yıllardan itibaren kentsel alandaki rolünün artmasında gelişen yapım teknolojisi, strüktür tasarımı ve malzeme olanaklarının etkili olduğu da söylenebilir.

\section{Değerlendirme ve Sonuç}

Günümüzde örnekleri daha çok görülmeye başlanan ve kullanımı artan geçici yapıların, insan, doğa, toplum ve teknoloji arasında aracı bir konumda, katalizör görevi gördüğü söylenebilir. İnsanları sosyalleşmeye, keşfetmeye yönlendirmesi, merak uyandırması ve çeşitli şekillerde bilgilendirmesi bakımından topluma yarar sağlayan bu yapıların, mimarinin gelişmesinde, yol almasında önemli katkısı bulunduğu düşünülmektedir. Geçicilik ile mimaride, kesin bir bağlama, belirli bir döneme ve birtakım sınırı niceliksel değerlere bağlı olma koşulu, yerini koşullara ve durumlara göre biçimini ve bulunduğu yeri değiştirebilmeye, inşa edilen alanda mekâna paralel biçimde zamanda var olmaya bırakmıştır. Bu yönüyle geçicilik ve geçici tasarımın, mimarlıkta temel kavramların yeniden yapılanmasını sağladığı söylenebilir. 
Kolay inşa edilebilmeleri, yerden bağımsız oluşları sayesinde tarihsel süreç içinde kamusal alanda daha çok yaygınlaşan bu yapılar, toplumsal hayatın zenginleşmesine ve kentin kimliğine katkı sağlayarak, insanları bir araya getiren, toplumsal üretimin ve paylaşımın oluştuğu mekânlar haline geldiği görülmektedir. Kent yaşamına belirli şekillerde adapte olan geçici yapıların kentsel boyutta, geçiciliği ve değişkenliğiyle kamusal alanlarda sürekli bir canlılık ve kullanım yoğunluğu sağlayabileceği de tespitler arasındadır. Bu özellikleriyle geçici yapıların toplumun yaşam biçimine etki ederek sosyal hayatın zenginleşmesine ve paralelinde kentsel ve toplumsal aidiyet duygusunun gelişmesine yardımcı olacağı söylenebilir.

Geçici yapıların yüzyıl başından günümüze gelene dek kendine özgü karakteristiğini oldukça belirginleştirdiği ve birtakım yapısal normlara dönüştürdüğü görülmüştür. Geçici olmak ve belirli bir süre için kullanılır olmak, bu yapıların daha hafif, daha geçirgen ve sınırlarının daha tanımsız olmasını sağlamıştır. Her ne kadar 1980-2000'li dönemlere dek geçici olmak tasarımda öncelikli bir parametre olmasa da taşınabilir, dönüşebilir, takılıp-sökülebilir strüktürle birlikte düşük maliyetli, hızlı üretilebilen ve hafif malzeme kullanımının artmasının yerden bağımsız olmayı kolaylaştırdığı ve geçici olma potansiyelini arttırdığı belirlenmiştir. Öte yandan formun yenilikçi ve yaratıcı etkisi her dönem için etkili bir unsur olarak belirmiştir. Dönemin intiyaçlarına değişim yoluyla cevap verebilen bu yapıların yaşantının hızının artmasıyla işlevsel çeşitliliğini ve biçimsel dinamiğini arttırdığı da söylenebilir.

Dönemin yenilikçi tasarım yaklaşımlarının ve teknolojik inşa yöntemlerinin kullanıldığı bu yapılar zamanının tasarım anlayışının temsili niteliğindedir. Nitekim tasarımın odağında olan ekoloji, sürdürülebilirlik gibi güncel konular ya da henüz yapılarda büyük ölçekte uygulanması ekonomik ya da teknik olarak mümkün olmayan yenilikçi ve teknolojik malzemelerin kullanımı geçici yapıların tasarım ve yapım pratiği içinde yer almıştır. Bu bakımdan geçici yapılar; mimari tasarım ve uygulama için adeta bir deney alanı, bir laboratuvar olarak tanımlanabilir.

\section{Kaynaklar}

Aksoy, Özgönül. Biçimlendirme. Karadeniz Teknik Üniversitesi, İnşaat Ve Mimarlık Fakültesi Yayınları, Trabzon. 1977.

Aksakal, Orçun. "Zaman Kavramı, Avrupa Seramik Masa ve Şömine Saatleri (18.Yüzyıl Başı- 19.Yüzyıl)", Sanat ve Tasarım Dergisi, 7 (1), 2011, s. 111-122

Altun, Didem. Dünya fuarlarının/expoların mimari değerlendirmesi: Türk pavyonları, Dokuz Eylül Üniversitesi, Fen Bilimleri Enstitüsü, Yüksek Lisans Tezi, İzmir, 2003.

Arun, Turhan, Geçici Mimari Yapılarda Grafik Ögelerin Kullanımı, Haliç Üniversitesi Sosyal Bilimler Enstitüsü, Yüksek Lisans Tezi, İstanbul. 2012.

Bancl, Selda, Turkish Pavilion In The Brussels Expo '58: A Study On Architectural Modernization In Turkey During The 1950s, Orta Doğu Teknik Üniversitesi, Sosyal Bilimler Enstitüsü, Yüksek lisans tezi. Ankara. 2009.

Brawne, Michael, Architectural Thought: the design process and the expectant eye, Architectural Press. Oxford, 2003. 
Cebriloğlu, Orhan, "21. Yüzyılda Sanatçının Kalıcı Olma Düşüncesine Karşı Ortaya Koyduğu Tavır", İdil Dergisi, 21 (5), 2016, s. 373-388.

Charleson, Andrew, Structure as Architecture 'A source book for architects and structural engineers', 1. B., New York: Routledge, 2006.

Chappel, Brian, Ephemeral Architecture: Towards A Definition (E-Kitap), 2004. https://fdocuments.net/document/ephemeral-architecture-569fe12db0ec1.html

Chabrowe, Barbara, "On the Significance of Temporary Architecture", The Burlington Magazine. 856 (116), 1973, s. 384-391.

Conway, Hazel; Roenisch, Rowan, Understanding Architecture an Introduction to Architecture and Architec-tural History, Routledge, London, 1994.

Crosby, Theo, "Design and Purpose in World Exhibitions", Journal of the Royal Society of Arts, 116(5139), 1968, s. 239-257. Erişim adresi: http://www.jstor.org/stable/41370073

Erman, Onur; Yılmaz, Nur, "Mimari Tasarımda Konsept ve Bağlam İlişkisi Üzerine", Uluslararası Hakemli Tasarım ve Mimarlık Dergisi, (10), 2017, s. 96-115.

Güzer, Abdi, "Mimarlıkta Gerçekle Taklidin Sınırları”, Mimarlık Dergisi. 333, 2007, Erişim adresi;

http://www.mimarlikdergisi.com/index.cfm?sayfa=mimarlik\&DergiSayi=51\&ReclD=1254

İzgi, Utarit, Mimarlıkta süreç: kavramlar-ilişkiler, Yapı-Endüstri Merkezi, İstanbul, 1999.

Jodidio, Philip, Temporary Architecture Now. 1.B., Taschen, Cologne, 2011.

Kavurmacıoğlu, Özgür, Arıdağ, Levent, "Strüktür Tasarımında Geometri ve Matematiksel Model İlişki", Beykent Üniversitesi Fen ve Mühendislik Bilimleri Dergisi, 2(6), 2013, s. 5976.

Kan Ülkü, Gözde, “Mimarlık ve Sanat İşbirliği: Brüksel EXPO'58 Türkiye Pavyonu”, IBAD Sosyal Bilimler Dergisi, (5), 2019, s. 497-516.

Naegele, Daniel, "Building Books: Le Courbusier's "Word-Image" Pavilions, an Architecture of Representation", Architecture Conference Proceedings and Presentations, 4, 2004, s. 458-464.

Robinson, Joel, "Introducing Pavilions: Big Worlds Under Little Tents", Open Arts Journal. 2, 2014, s. 1-22.

Salvan, George, Architectural Theory of Design, 3. B., JMC Press, INC, Quezon City, 1999.

Sdegno Aberto; Ranon Roberto; Bernal Pedro; Masserano Silvia; Cochelli Paola, "Reloading Le Corbusier's Architectures with New Technologies for Advanced Visualization of Cultural Heritage" New Activities for Cultural Heritage Proceedings of the International Conference HeritageBot 2017, Ed.: Ceccarelli, Marco; Cigola, Michela; Recinto, Giuseppe, Springer, İtalya, 2017, s. 166-173. 
Taşkın, Aytaç, Kolonun Mimari Tasarımda Rolünün Değerlendirilmesi, Çukurova Üniversitesi Fen Bilimleri Enstitüsü, Yüksek Lisans Tezi, Adana, 2019.

Toffler, Alvin, Gelecek Korkusu 'Şok', 1. B., Çev.: (Selami Sargut), Altın Kitaplar Basımevi, İstanbul, 1974.

Udovicki-Selb Danilo, The Elusıve Faces of Modernity: The Inventıon of the Parıs 1937 Exhibition and the Temps Nouveaux Pavilion, MIT Dept. of Urban Studies and Planning, Doktora Tezi, Massachusetts, 1995.

Yıldırım, Erdem, Foto-Mekân, Foto-Hikâye, Foto-Duvar: Le Corbusier Mimarliği ve Onun Fotografik Temsili, Dokuz Eylül Üniversitesi, Fen Bilimleri Enstitüsü, Yüksek Lisans Tezi, İzmir, 2009.

\section{İnternet Kaynakları}

URL-1: What is the meaning of The Scream?. Erişim tarihi: 28.05.2021, 10:04.

https://www.bbc.com/culture/article/20160303-what-is-the-meaning-of-the-scream

URL-2: Desert paintbrush (Castilleja chromosa) Butler Ruins, Blanding, Utah. Erişim tarihi: 28.05.2021, 10:11.

https://thesouloftheearth.com/castilleja-beautiful-vampires/

URL-3: Three Mayfly on Crested Dogstail, Luminar bug photographer of the year, Erişim tarihi: 28.05.2021, 10:22.

https://www.photocrowd.com/photographer-community/15114/

URL-4: Eyfel Kulesi, Erişim tarihi: 28.05.2021, 10:25.

https://www.arkitektuel.com/eyfel-kulesi/

URL-5: The Temple of Ancient Virtue, Buckinghamshire. Erişim tarihi: 28.05.2021, 10:25.

https://www.nationaltrust.org.uk/stowe/profiles/william-kent---profile

URL-6: National Stadium, Beijing, Arquitectura Viva 118-119: 82-101, Erişim tarihi: 28.05.2021, 10:26.

https://arquitecturaviva.com/works/estadio-nacional-en-pekin-6

URL-7: AD Classics: Gwathmey Residence and Studio / Charles Gwathmey, Erişim tarihi: 28.05.2021, 10:33.

https://www.archdaily.com/60778/ad-classics-gwathemy-residence-and-studio-charlesgwathmey

URL-8: Guggenheim Museum Bilbao. Bilbao. Erişim tarihi: 28.05.2021, 10:39.

https://unsplash.com/s/photos/guggenheim-museum-bilbao

URL-9: Exterior of the Solomon R. Guggenheim Museum. New York, NY. Erişim tarihi: 28.05.2021, 10:51.

https://www.guggenheim.org/the-frank-lloyd-wright-building/timeline

URL-10: Yalın, Fonksiyonel ve İlhamını Köklerinden Alan Yapıların Mimarı: Nevzat Sayın, Erişim tarihi: 28.05.2021, 10:55. 
https://www.oggusto.com/dekorasyon/yalin-fonksiyonel-ve-ilhamini-koklerinden-alanyapilarin-mimari-nevzat-sayin

URL-11: Pavillon de l'Esprit Nouveau, Paris, France, 1924. Erişim tarihi: 28.05.2021, 11:00.

http://www.fondationlecorbusier.fr/corbuweb/morpheus.aspx?sysld=11\&sysLanguage= en-en\&sysParentld=11\&sysParentName=home\&clearQuery $=1$

URL-12: L'Esprit Nouveau Pavilion. Erişim tarihi: 28.05.2021, 11:03.

https://en.wikiarquitectura.com/building/lesprit-nouveau-pavilion/\#

URL-13: Montreal Biosphère of 1967 / Buckminster Fuller. Montreal, Kanada. Erişim tarihi: 28.05.2021, 11:04.

https://archeyes.com/montreal-biosphere-1967-buckminster-fuller/

URL-14: Montreal Biosphere / Buckminster Fuller. Erişim tarihi: 28.05.2021, 11:07. https://www.archdaily.com/572135/ad-classics-montreal-biosphere-buckminsterfuller?ad_source=search\&ad_medium=search_result_projects

URL-15: Jeodezik kubbelerin dikkat çeken örneği: Biyosfer Montreal, Erişim tarihi: 28.05.2021, 11:10.

https://www.gzt.com/arkitekt/jeodezik-kubbelerin-dikkat-ceken-ornegi-biyosfermontreal-3567756

URL-16: IBM Travelling Pavillion. Erişim tarihi: 28.05.2021, 11:10.

https://mjobrienarchitect.com/Piano_IBM.pdf

URL-17: IBM Travelling Pavillion. Erişim tarihi: 28.05.2021, 11:17.

https://mjobrienarchitect.com/Piano_IBM.pdf

URL-18: Renzo Piano Building Workshop Selected Projects: Part 3. Erişim tarihi: 28.05.2021, 11:19.

https://archleague.org/article/renzo-piano-building-workshop-selected-projects-part-3/

URL-19: Cardiff Bay Visitor's Centre. Erişim tarihi: 28.05.2021, 11:22.

https://all.design/willalsop/cardiffbay

URL-20: Cardiff Bay Visitors Centre. Erişim tarihi: 28.05.2021, 11:22.

https://www.architen.com/projects/cardiff-bay-visitors-centre/

URL-21: Cardiff Bay Visitors Centre. Erişim tarihi: 28.05.2021, 11:23.

https://www.ajbuildingslibrary.co.uk/projects/display/id/1258

URL-22. The Kitchen Monument (dismantled). Erişim tarihi: 28.05.2021, 11:27.

https://raumlabor.net/tempelhof-workshop/

URL-23: Küchenmonument. Erişim tarihi: 28.05.2021, 11:28.

https://www.detail.de/artikel/kuechenmonument-1005/

URL-24: Das Küchenmonument. Erişim tarihi: 28.05.2021, 11:29.

https://raumlabor.net/kuchenmonument/

URL-22: Serpentine Pavilion 2015. Erişim tarihi: 28.05.2021, 11:29.

https://archello.com/project/serpentine-pavilion-2015 
URL- 26: Serpentine Pavilion 2015 by selgascano. Erişim tarihi: 28.05.2021, 11:37. https://www.serpentinegalleries.org/whats-on/serpentine-pavilion-2015-designedselgascano/

URL- 27: Selgascano's 2015 serpentine pavilion re-opens in los Angeles. Erişim tarihi: 28.05.2021, 11:37.

https://www.designboom.com/architecture/selgascano-2015-serpentine-pavilionsecond-home-los-angeles-04-24-2019/ 